\title{
Combining Ability Study in a 6 × 6 Diallel Cross of Maize
}

\author{
Amanullah $^{\mathrm{a} *}$, Shah Jehan Khan ${ }^{\mathrm{a}}$ and Muhammad Mansoor ${ }^{\mathrm{b}}$ \\ ${ }^{a}$ Faculty of Agriculture, Gomal University, Dera Ismail Khan, Pakistan \\ ${ }^{\mathrm{b}}$ Arid Zone Research Institute, Ratta Kulachi, Dera Ismail Khan, Pakistan
}

(received March 29, 2010; revised December 23, 2010; accepted December 28, 2010)

\begin{abstract}
The $\mathrm{F}_{1}$ generation of $6 \times 6$ diallel cross in maize was evaluated for combining ability under irrigated conditions of Dera Ismial Khan, Pakistan. Based on the variance data, general combining ability (GCA) and specific combining ability (SCA) showed the importance of additive gene effect in some characters under study like kernel rows/ear, kernels/row, kernels/ear, 1000 grain weight and grain yield. The results showed that $F_{1}$ mean squares due to GCA were highly significant for all the parameters under observation. Higher magnitude of GCA components of variance (\%) for kernels/ear, 1000 grain weight and grain yield, indicated predominance of additive and additive type of gene action while for kernel rows/ear, and kernels/row, nearly equal importance of both additive and non-additive gene effects were observed. The estimates of GCA effects revealed that parents Jalal and Sarhad White were good general combiners for most of the traits under discussion. The crosses, Kisan $\times$ Azam and Azam $\times$ Sadaf showed good SCA effects with excellent mean performance for most of the traits studied in $\mathrm{F}_{1}$.
\end{abstract}

Keywords: combining ability, diallel cross, Zea mays L.

\section{Introduction}

Maize is grown over a diverse environment ranging from tropical to north latitude. However, in Pakistan it is mainly grown in provinces of Punjab and NWFP during spring and summer seasons. Its global average is much higher than average yield of Pakistan. The global area under maize crop is 147.56 million hectares producing 701.273 million metric tons with average yield of $4752 \mathrm{~kg} / \mathrm{ha}$. In Pakistan, it is cultivated on 1017 thousand hectares with annual production of 3088 thousand tons and average yield of $3036 \mathrm{~kg} / \mathrm{ha}$ (Federal Bureau of Statistic, 20062007).

Utilization of hybrid vigour has proved successful for increased productivity of maize crop in almost all the countries of the world. Combining ability analysis assumes considerable importance as it is a established fact that all the lines cannot produce good hybrids as compared to other lines producing superior hybrids. The frequencies of desirable inbred lines, in maize, have been placed between 0.1 and 0.01 percent (Wang et al., 2007).

The conventional crop breeding methodology mainly depends upon the development of inbred lines of maize from open pollinated varieties or other heterogeneous sources and their evaluation for commercial use.

*Author for correspondence; E-mail: panyala64@yahoo.com
General combining ability (GCA) and specific combining ability (SCA) effects were more important for kernel rows and additive genetic variance was predominant for all the grain characters (Bagheri and Jelodar, 2010).

The present investigation was undertaken to characterize six varieties and their $30 \mathrm{~F}_{1}$ cross combinations for their general and specific combining ability effects, respectively, and identify the potential hybrids for cultivation under agro-climatic conditions of Dera Ismail Khan, Pakistan. The reason for selection of these six maize varieties was that these varieties were promising and acclimatized to the climatic conditions of the area. Unfortunately, their performance varied from character to character i.e., one variety was better in one character and the other was better in other character, hence, keeping in view their GCA and SCA, we were trying to explore their exploitation in breeding programme.

\section{Materials and Methods}

Six maize varieties namely, Kisan, Azam, Sarhad White, Sarhad Yellow, Jalal and Sadaf were evaluated in a full diallel mating design to generate $30 \mathrm{~F}_{1}$ crosses. Five plants were involved in each cross. The parents and their crosses were evaluated at Agricultural Research Institute, Ratta Kulachi, Dera Ismail Khan during Kharif (rainy) season of 2005.The experimental material was 
arranged in a randomized complete block design (RCBD) with four replications. Each entry was sown in four rows of $5 \mathrm{~m}$ length having row to row distance of $75 \mathrm{~cm}$ and plant to plant spacing of $20 \mathrm{~cm}$. Planting was done on ridges using 2-3 seeds per hill with the help of dibbler. Plants were thinned to one plant per hill when the plants reached to four-leaf stage. Fertilizer was applied @ 150-75 NP kg/ha; nitrogen and phosphorus were applied in the form of urea and DAP, respectively. All the phosphorus and half dose of nitrogen were applied at seedbed preparation and the remaining dose of urea was applied when the plants attained knee height. Other cultural practices and protection measures were carried out according to the recommended procedure for D. I. Khan. The data were recorded for six traits i.e., kernels/ear, kernel rows/ear, kernels/row, 1000 grain weight, ear length and grain yield.

Numbers of kernels/row were counted from 10 ears randomly selected from each plot, and then average was calculated. Number of kernels/ear was counted in 10 randomly selected plants in each plot. Total number of kernels divided by 10 gave the average number of kernels/ear. Ten ears randomly selected from each plot were measured and the average ear length was calculated. 1000 grain weight was calculated with the help of electronic balance, up to two decimal points, from the bulk produce of 10 randomly selected plants of each plot. Grain yield was calculated using fresh ear weight at harvest, assuming $80 \%$ shelling and adjusted to $15 \%$ moisture content. Combining ability analysis was performed using Griffing (1956) method-2 model-II.

\section{Results and Discussion}

Pooled analysis of variance for combining ability (Table 1) indicated the presence of high significance of mean squares due to GCA, SCA and reciprocal effects for all the characters studied, indicating there by the differences among parental lines for GCA and among crosses for SCA effects. The ratio of estimated GCA to SCA variance indicated the preponderance of the latter component in controlling the expression of all the traits. The SCA variance involves both dominance and epistasis which together constitute the non-additive type of gene action, whereas the GCA variance is a reflection of additive and additive $x$ additive type of gene action. The non-additive component of gene action could be optimized in upgrading the genetic potential of the crop by adopting reciprocal recurrent selection and hybrid technology, which has already become a field reality in maize breeding.

The perusal of Table 2 enunciated that the GCA components of variance (\%) were greater in magnitude and more important for kernel rows/ear (28.21), kernels/row (19.07), kernels/ear (26.61), 1000 grain weight (24.04 g) and grain yield (39.02 kg/ha), thereby showing the predominance of additive type of gene action for inheritance of the above characters. These findings for additive type of gene action for different parameters corroborate the conclusion drawn by earlier workers (Haq et al., 2010; Akbar et al., 2009; Ojo et al., 2007). However, some researchers had observed non-additive type of gene action for most of the traits and such deviations may be due to different genetic background of the cultivars used and different environmental conditions encountered.

In case of reciprocal variance (Table 2), some traits exhibited smaller values as compared to GCA and SCA except kernels/row (57.73) and 1000 grain weight (60.23 g). It is relevant that the maternal effect for the above traits were due to plasma gene action which is found rarely in such diallel studies. These results are

Table 1. Pooled analysis of variances for different traits in a $6 \times 6$ variety diallel of maize

\begin{tabular}{llllllll}
\hline \hline $\begin{array}{l}\text { Source of } \\
\text { variation }\end{array}$ & DF & Kernels/ear & Kernel rows/ear & Kernels/row & $\begin{array}{l}1000 \text { Grain } \\
\text { weight (g) }\end{array}$ & Ear length (cm) & $\begin{array}{l}\text { Grain yield } \\
(\mathrm{kg} / \mathrm{ha})\end{array}$ \\
\hline GCA & 5 & $2580.81^{*}$ & $3.04^{*}$ & $4.80^{*}$ & $1625.80^{*}$ & $4.364^{*}$ & $1737399^{*}$ \\
SCA & 15 & $475.59^{*}$ & $0.45^{*}$ & $0.35^{*}$ & $58.70^{*}$ & $0.40^{*}$ & $164628.7 *$ \\
Reciprocal & 15 & $466.60^{*}$ & $0.64^{*}$ & $2.84^{*}$ & $314.77^{*}$ & $1.20^{*}$ & $228674.9 *$ \\
Error & 105 & 304.36 & 0.22 & 0.60 & 58.70 & 0.25 & 57687.33 \\
\hline \hline
\end{tabular}

*=significant @ 0.05 probability. 
closely supported by Kenga et al. (2005) and Long et al. (2004) who noticed some reciprocal variance showing positive maternal effects for different parameters.

The perusal of GCA effects (Table 3) revealed that Azam was an ideal general combiner for three characters i.e. kernel rows/ear (0.82), kernels/row (0.97) and 1000 grain weight (19.14 g) while the same cultivar exhibited negative GCA effect for one character under discussion i.e. kernels/ear (-26.69). The Kisan variety surpassed and produced maximum GCA effects for kernels/ear (14.29) and grain yield (241.99 kg/ha). The same variety performed as the second best general combiner for 2 traits i.e. kernel rows/ear (0.42) and kernels/row (0.34) under study. The variance due to GCA showed the importance of both additive and non-additive gene effects in the inheritance of almost all the characters studied. These results are in line with the findings of Bello and Olaoye (2009) and Viana (2007).
Estimates of SCA effects of the crosses are presented in Table 4. The $\mathrm{F}_{1}$ hybrid (Kisan $\mathrm{x}$ Sadaf) was the best specific combination for exploitation of positive SCA effects for the characters under study. The hybrid (Azam x Sadaf) produced the highest SCA values for the traits like kernels/ear (33.77) and kernel rows/ear (0.93). For kernels/row cross combination, Azam x Sarhad Yellow with value of 0.81 , for 1000 grain weight Sarhad White x Sarhad Yellow with value of $7.63 \mathrm{~g}$, for ear length Kisan $x$ Sadaf with value of $0.49 \mathrm{~cm}$ and for grain yield Sarhad White $\mathrm{x}$ Jalal remained the topper with SCA value of $449.36 \mathrm{~kg} / \mathrm{ha}$. In the above crosses it is obvious that when Azam variety was used as female parent, the cross showed maximum SCA effect; moreover the GCA estimates depict that Azam had positive and prominent GCA effect for three traits. As depicted through the values given against each parent, it can be concluded that comparatively low $\mathrm{x}$ high parents performed well in SCA determination. These results are in line with the findings of Mufti

Table 2. Estimates of components of variance and their percentages in parenthesis due to general, specific combining ability and reciprocal effects for various traits in $6 \times 6$ variety diallel maize

\begin{tabular}{lllllll}
\hline \hline $\begin{array}{l}\text { Components of } \\
\text { variation }\end{array}$ & Kernel rows/ear & Kernels/row & Kernels/ear & $\begin{array}{l}1000 \text { Grain } \\
\text { weight (g) }\end{array}$ & Ear length (cm) & $\begin{array}{l}\text { Grain yield } \\
(\mathrm{kg} / \mathrm{ha})\end{array}$ \\
\hline GCA & 0.22 & 0.37 & 175.89 & 125.38 & 0.33 & $\begin{array}{l}131351.7 \\
(39.02)\end{array}$ \\
SCA & $(28.21)$ & $(19.07)$ & $(26.61)$ & $(24.04)$ & 0.09 & 62095.0 \\
& 0.13 & -0.15 & 99.42 & 58.70 & $(18.95)$ & $(18.45)$ \\
Reciprocal & $(16.66)$ & $(-7.73)$ & $(15.04)$ & $(11.25)$ & $(7.89)$ & 85493.8 \\
& 0.21 & 1.12 & 81.12 & 314.20 & 0.47 & $(25.39)$ \\
Error & $(26.92)$ & $(57.73)$ & $(12.28)$ & $(60.23)$ & $(41.23)$ & 57687.3 \\
& 0.22 & 0.60 & 304.36 & 23.37 & 0.25 & $(17.14)$ \\
Total & $(28.21)$ & $(30.93)$ & $(46.06)$ & $(4.48)$ & $(21.93)$ & 336627.8 \\
& 0.78 & 1.94 & 660.79 & 521.65 & 1.14 & 100 \\
\hline \hline
\end{tabular}

Table 3. Estimates of GCA effects for different traits of $6 \times 6$ variety diallel of maize

\begin{tabular}{lllllll}
\hline \hline Varieties & Kernel rows/ear & Kernels/row & Kernels/ear & 1000 Grain weight (g) & Ear length (cm) & Grain yield (kg/ha) \\
\hline Kisan & 0.42 & 0.34 & 14.29 & -5.81 & -0.16 & 241.99 \\
Azam & 0.82 & 0.97 & -26.69 & 19.14 & 0.17 & 223.79 \\
Sarhad W & -0.14 & -0.08 & -4.04 & 2.73 & 0.57 & 123.43 \\
Sarhad Y & -0.39 & -0.64 & 0.31 & -13.21 & -1.04 & -101.40 \\
Jalal & -0.45 & -0.72 & 10.56 & -8.19 & -0.14 & -729.07 \\
Sadaf & -0.24 & 0.13 & 5.56 & 5.33 & 0.60 & 241.26 \\
CD(gi-gi)* & 0.38 & 0.62 & 13.96 & 3.87 & 0.40 & 192.19 \\
\hline \hline
\end{tabular}

*gi = GCA effects for line i. 
Table 4. Estimates of SCA effects of $F_{1}$ crosses from $6 \times 6$ variety diallel of maize

\begin{tabular}{|c|c|c|c|c|c|c|}
\hline F1 Hybrids & Kernels/ear & Kernels rows/ear & Kernels/row & $\begin{array}{l}1000 \text { Grain } \\
\text { weight (g) }\end{array}$ & Ear length (cm) & $\begin{array}{l}\text { Seed yield } \\
(\mathrm{kg} / \mathrm{ha})\end{array}$ \\
\hline Kisan $\times$ Azam & -31.58 & -0.09 & 0.33 & 4.05 & -0.22 & 69.69 \\
\hline Kisan $\times$ Sarhad White & 7.52 & -0.13 & -0.26 & 2.30 & 0.39 & 27.67 \\
\hline Kisan $\times$ Sarhad Yellow & 0.54 & -0.01 & -0.44 & -1.56 & -0.01 & -338.87 \\
\hline Kisan $\times$ Jalal & 14.92 & -0.44 & 0.14 & -1.66 & -0.28 & -15.70 \\
\hline Kisan $\times$ Sadaf & 2.04 & 0.60 & 0.16 & -3.44 & 0.49 & 260.72 \\
\hline Azam × Sarhad White & 13.25 & -0.67 & -0.38 & 3.35 & 0.10 & 18.13 \\
\hline Azam $\times$ Sarhad Yellow & 13.52 & -0.05 & 0.81 & -22.13 & -0.22 & -150.04 \\
\hline Azam $\times$ Jalal & -0.98 & -0.36 & 0.01 & 2.94 & -0.11 & 218.01 \\
\hline Azam $\times$ Sadaf & 33.77 & 0.93 & -0.59 & -5.24 & -0.01 & -79.70 \\
\hline Sarhad W $\times$ Sarhad Y & -3.75 & 0.16 & 0.22 & 7.63 & -0.49 & -2.18 \\
\hline Sarhad White $\times$ Jalal & -0.13 & 0.35 & 0.31 & -6.80 & -0.38 & 449.36 \\
\hline Sarhad White $\times$ Sadaf & -13.63 & 0.14 & 0.20 & -3.53 & -0.86 & -440.35 \\
\hline Sarhad Yellow $\times$ Jalal & -3.85 & 0.22 & -0.13 & 2.09 & -0.48 & 243.69 \\
\hline Sarhad Yellow $\times$ Sadaf & -5.48 & -0.74 & -0.49 & 7.60 & -0.37 & 360.11 \\
\hline Jalal $\times$ Sadaf & -9.98 & -0.05 & 0.47 & 2.48 & 0.22 & -463.47 \\
\hline CD(sij*-slk) & 31.21 & 0.84 & 1.39 & $8 . .65$ & 0.89 & 429.74 \\
\hline CD(sij*-skl) & 27.92 & 0.75 & 1.24 & 7.74 & 0.80 & 384.37 \\
\hline
\end{tabular}

*sij = specific combining ability between ith and jth line.

et al. (2002) who reported that parent with the best GCA, used as pollen parent, always produced better combinations.

\section{Conclusion}

Variety Jalal followed by Sarhad White proved to be good general combiners for most of the traits under discussion. The cross Kisan $\times$ Sadaf showed positive SCA effects for all the traits under study in $\mathrm{F}_{1}$ generation. Though cultivar Sadaf remained on top in only one trait i.e. ear length but its combination with the other cultivars produced the best specific combinations. Hence, it is concluded that comparatively low $\times$ high parents performed well in SCA determination and resulted in superior combinations.

\section{References}

Akbar, M., Saleem, M., Ashraf, M.Y., Husain, A., Azhar, F.M., Ahmad, R. 2009. Combining ability studies for physiological and grain yield traits in maize at two temperature regimes. Pakistan Journal of Botany, 41: 1817-1829.

Bagheri, N., Jelodar, N.B. 2010. Heterosis and combining ability analysis for yield and related-yield traits in hybrid rice. International Journal of Biology, 2: 222-231.
Bello, O.B., Olaoye, G. 2009. Combining ability for maize grain yield and other agronomic characters in a typical southern guinea savanna ecology of Nigeria. African Journal of Biotechnology, 8: 2518-2522.

Federal Bureau of Statistic, 2006-07. Agricultural Statistics of Pakistan, pp. 23-24, Ministry of Food, Agriculture and Livestock, Economic Wing, Islamabad. Government of Pakistan.

Griffing, B. 1956. Concept of general and specific combining ability in relation to diallel crossing systems. Australian Journal of Biological Sciences, 9: 463-493.

Haq, M.I, Ajmal, S., Munir, M., Gulfaraz, M. 2010. Gene action studies of different quantitative traits in maize. Pakistan Journal of Botany, 42: 10211030.

Kenga, R., Alabi, S.O., Gupta, S.C. 2005. Heterosis and combining ability for grain yield and its components in induced sorghum mutants. African Crop Science Journal, 13: 143-152.

Long, J.K., Banziger, M., Smith, M.E. 2004. Diallel analysis of grain iron and zinc density in Southern African-adapted maize inbreds. Crop Science, 44: 2019-2026.

Mufti, M.U., Saleem, M., Hussain, A. 2002. Diallel 
analysis of yield and yield components in maize (Zea mays L.). Pakistan Journal of Agriculture Research, 17: 22-26.

Ojo, G.O.S., Adedzwa, D.K., Bello, L.L. 2007. Combining ability estimates and heterosis for grain yield and yield components in maize (Zea mays L.). Journal of Sustainable Development in Agriculture and Environmental, 3: 49-57.
Viana, J.M. 2007. Heterosis and combining ability analyses from the partial diallel. Bragantia: Revista de Ciencias Agronomicas, 66: 51-60.

Wang, Y., Fu, S., Wen, Y., Zhang, Z., Xia, Y., Liu, Y., Rong, T., Pan, G. 2007. Selection of maize inbred lines with high regeneration and susceptibility to Agrobacterium tumifacien. Journal of Genetics and Genomics, 34: 749-755. 